\title{
In vitro expression of the recombinant fusion protein of Newcastle disease virus from local Indonesian isolates by using a cell-free protein expression system
}

\author{
Aris Haryanto ${ }^{1}$, Hevi Wihadmadyatami ${ }^{2}$, Nastiti Wijayanti ${ }^{3,{ }^{*}}$ \\ ${ }^{1}$ Department of Biochemistry and Molecular Biology, Faculty of Veterinary Medicine, Universitas Gadjah Mada, Jl. Fauna No. 2, Karang- \\ malang, Yogyakarta 55281, Indonesia \\ ${ }^{2}$ Department of Anatomy, Faculty of Veterinary Medicine, Universitas Gadjah Mada, Jl. Fauna No. 2, Karangmalang, Yogyakarta 55281, \\ Indonesia \\ ${ }^{*}$ Corresponding author: nastiti_wijayanti@ugm.ac.id
}

SUBMITTED 6 March 2020 REVISED 23 April 2020 ACCEPTED 8 June 2020

\begin{abstract}
The aim of this work was the in vitro expression of the recombinant fusion (F) protein of Newcastle disease virus (NDV). The pBT7-N-His-Fusion-NDV expression plasmid which carries the recombinant F protein encoding gene from local Indonesian isolates, was prepared and transformed into Escherichia coli BL21 (DE3). To detect bacterial colonies carrying the recombinant plasmid, a restriction endonuclease analysis was performed using the EcoRI restriction endonuclease. These results showed that the pBT-N-His-Fusion-NDV plasmid was successfully isolated with a size of $4.601 \mathrm{bp}$, and three recombinant plasmids carrying the gene coding for the recombinant F protein of NDV were obtained. Selected recombinant plasmids were then in vitro by using a cell-free protein expression system followed by visualization of the recombinant $F$ protein on a $12 \%$ SDS-PAGE gel both by Coomassie Brilliant Blue staining and Western blotting. Recombinant F protein was successfully in vitro expressed by using a cell-free protein expression system as indicated by a specific single protein band with a molecular mass of $25.6 \mathrm{kDa}$.
\end{abstract}

KEYWORDS cell-free protein expression; in vitro expression; Newcastle diseases virus (NDV); recombinant F protein

\section{Introduction}

Newcastle disease (ND) is a poultry infectious viral disease which has become a major problem in the poultry industry in developing countries. Office International des Epizooties (OIE) categorizes ND in the A list of animal diseases, which includes infectious diseases with rapid and serious spreading and affecting public health and socioeconomic communities ([OIE] Office Internationalof Epizootics 2015). As other infectious viral disease outbreak which had been reported in Indonesia poultry industry, such as avian influenza (Njoto et al. 2018), infectious bursal disease (Parede et al. 2003), and avian encephalomyelitis (Haryanto et al. 2016). An outbreak of ND can cause a devastating effect as it causes almost $100 \%$ mortality in susceptible poultry (Alexander et al. 2012). ND was also reported to have a significant economic effect on the poultry industry in Indonesia (Dharmayanti et al. 2014). Newcastle disease is caused by avian paramyxovirus serotipe-1 (APMV-1) virus, which is also known as Newcastle disease virus or NDV (Alexander 2003). NDV belongs to the genus Avulavirus, subfamili Paramyxovirinae, famili Paramyxoviridae, and order Mononegavirales (King et al.
2012). NDV genome is a negative sense single stranded RNA (ssRNA) encoding six viral proteins, namely nucleocapsid $(\mathrm{N})$, phosphoprotein $(\mathrm{P})$, matrix $(\mathrm{M})$, fusion protein (F), hemaglutinin-neuraminidase (HN), and RNA polymerase (L) (De Leeuw and Peeters 1999; King et al. 2012). NDV infection on the host cell is mediated by two surface viral glycoproteins, the hemaglutinin-heuraminidase (HN) protein and fusion (F) protein (Chang and Dutch 2012).

F protein in NDV plays an essential role in the virulence of the virus (Dortmans et al. 2011). F protein can also induce protective immunity against NDV infection (Arora et al. 2010). Kim et al. (2013) reported that the F protein of NDV is a major part of protective immunity in developing genotype-matched vaccine. NDV F protein consists of 553 amino acids which are synthesized as $\mathrm{F}_{0}$ inactive precursor (Morrison 2003). $F_{0}$ protein can be cleaved by cellular protease resulting in active $F_{1}$ and $F_{2}$ proteins. $F$ protein is processed in trans Golgi in a mammalian cell, which produces the active form of $\mathrm{F}_{1}-\mathrm{F}_{2}$ protein with a disulfide bond (Lamb and Parks 2007). The specificity of cleavage F protein is determined by the amino acid sequence at the region of cleavage sites and varied between strain types. 
In the cleavage site of F protein, low virulence NDV has one or two base amino acids. Therefore, low virulence NDV is not sensitive to intracellular protease enzyme and depends on extracellular protease in the respiratory and enteric systems of the host cells. Highly virulence NDV has multi base amino acids in the cleavage site so that it can be recognized by intracellular protease enzyme. Amino acid sequence at the cleavage site of $\mathrm{F}_{0}$ protein is one of the factors that determines the systemic spreading and virulence of NDV. Highly virulence NDV contains lysine (K) and arginine (R) amino acids with ${ }^{112} \mathrm{R}-\mathrm{R}-\mathrm{Q}-\mathrm{R} / \mathrm{K}-\mathrm{R}^{116}$ motive at $\mathrm{C}$ terminus $\mathrm{F}_{2}$ and phenylalanine $(\mathrm{F})$ amino acid at 117 position at $\mathrm{N}$ terminus protein $\mathrm{F}_{1}$ (Ganar et al. 2014).

Newcastle disease outbreak was reported in 20092010 in poultry farms in Indonesia, which caused death on $70-80 \%$ of the total number of chickens (Dharmayanti et al. 2014). Analysis on the amino acid identity of F and HN protein sequences from eight isolates NDV, which caused the outbreak indicated antigenic differences from La Sota and B1 vaccine strains (Xiao et al. 2012). A vaccination program has been conducted to prevent and overcome ND ([OIE] Office International of Epizootics 2012). However, ND outbreaks still continue to happen in Indonesia. The outbreak is a result from antigenic differences between NDV strain causing the outbreak in the field with NDV strain used in the available commercial vaccine. Therefore, the vaccination program did not provide optimal protection in the poultry post vaccination (Xiao et al. 2012; Dharmayanti et al. 2014).

A recombinant vaccine is a vaccine containing antigen of a pathogenic agent that can induce the host immunity against the pathogenic agent (Grand et al. 2012). The recombinant vaccine is safer and more stable compared to conventional live vaccines. A recombinant vaccine is created by cloning a certain encoding gene of an immunogenic protein, expressed and purified the recombinant protein, and formulated it to be a vaccine (Nascimento and Leite 2012). Regardless of the type of ND vaccines in use, all vaccinated birds were fully protected from disease. All vaccinated and challenged birds show significant seroconversion after 14 days of challenge. However, some vaccinated birds were reported to shed the challenge virus from their oro-pharynx and cloaca, even though they are significantly lower in titers than unvaccinated challenged control birds (Jeon et al. 2008).

The development of NDV vaccines based on the phylogenetic similarity to NDV in the time of the outbreak can provide better protection against ND (Miller et al. 2007). Therefore, one of the attempts to prevent ND on poultry in Indonesia is developing an ND vaccine based on local isolates originated in Indonesia. This work aimed to express recombinant F protein of NDV from pBT7-N-HisFusion-NDV expression vector which carries the F protein encoding gene from NDV local isolate by a cell-free protein expression system. Recombinant NDV F protein obtained from the expression is expected to be a candidate for the recombinant $\mathrm{F}$ vaccine to prevent ND on poultry in Indonesia.

\section{Materials and Methods}

\subsection{Preparation of pBT7-N-His-Fusion-NDV recombi- nant plasmid}

The expression vector used in this work had been prepared by Haryanto et al. (2016) and Wulanjati et al. (2018) by subcloning the F protein encoding gene of NDV from local isolate in Kulon Progo, Indonesia (0663/04/2013) into pBT7-N-His expression vector. The design of the recombinant plasmid vector is shown in Figure 1.

\subsection{Transformation of recombinant plasmid into Es- cherichia coli BL21 (DE3)}

Transformation of DNA plasmid pBT7-N-His-FusionNDV was carried out using competent Escherichia coli BL21 (DE3) strain by carefully transferring DNA plasmid into a tube containing competent cells. Plasmid DNA and competent cells were mixed gently and placed on ice for $20 \mathrm{~min}$. Then, the cells were heat-shocked at $42{ }^{\circ} \mathrm{C}$ for 60 $\mathrm{s}$. The mixture of plasmid DNA and competent cells were placed immediately on ice for $3 \mathrm{~min}$. The mixture was then put into the culture medium, $10 \mathrm{~mL}$ of Luria Bertani (LB) (Oxoid) supplemented with $100 \mu \mathrm{g} / \mathrm{mL}$ ampicillin (Gold Biotechnology), and incubated at $37^{\circ} \mathrm{C}$ overnight. The transformation of the recombinant plasmid into $E$. coli generated eight growing colonies of $E$. coli carrying recombinant plasmid. The eight colonies of bacteria were extracted using Presto Mini Plasmid kit (Geneaid) to obtain the recombinant plasmid DNA.

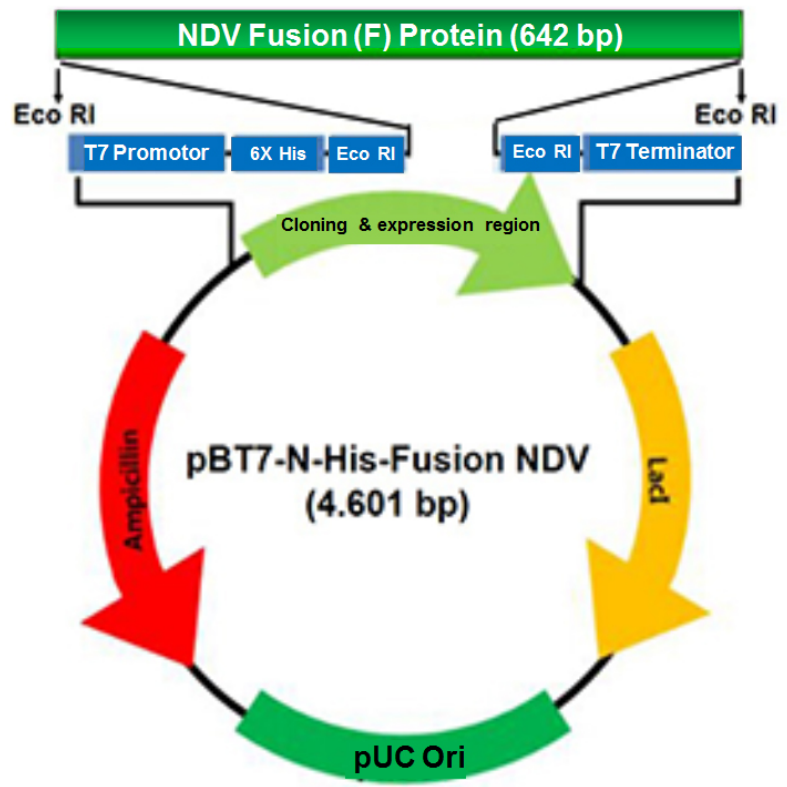

FIGURE 1 Design of recombinant plasmid pBT7-N-His-Fusion NDV (4,601 bp). F protein encoding gene of NDV (642 bp) was subcloned into the Eco RI restriction site 


\subsection{Restriction endonuclease analysis of recombinant plasmid vector by EcoRI enzyme}

The screening of recombinant plasmid pBT7-N-HisFusion-NDV was carried out by digestion of recombinant plasmid by EcoRI enzyme (Thermo Fisher Scientific) in a total volume of $10 \mu \mathrm{L}$. The samples were then incubated at $37{ }^{\circ} \mathrm{C}$ for $3 \mathrm{~h}$. The digestion product was then visualized on a $1.5 \%$ agarose gel electrophoresis with Fluorosafe (Genetika Science Indonesia) staining. The restriction product was analyzed under UV light in the dark room.

\subsection{In vitro expression of recombinant FpProtein of NDV by the cell-free protein expression system}

The in vitro expression of recombinant F protein of NDV from Indonesian local isolates was performed by a cellfree protein expression system using the AccuRapid protein expression kit (Bioneer) according to the standard manual procedure. The expressed recombinant F protein of NDV was then visualized by electrophoresis on an SDSPAGE gel followed by Coomassie Brilliant Blue R-250 (Thermo Fisher Scientific) staining.

\subsection{SDS-PAGE with Coomassie Brilliant Blue staining}

Before SDS-PAGE, the samples were denatured at $95{ }^{\circ} \mathrm{C}$ for $5 \mathrm{~min}$, then put into ice for about $30 \mathrm{~min}$. Each sample $(5 \mu \mathrm{L})$ was loaded on a $5 \%$ stacking gel and separated on a $12 \%$ resolving SDS-PAGE gel. The protein concentration of each sample was as follow $1.39 \mu \mathrm{g} / \mu \mathrm{L}$ for sample 1 , $0.13 \mu \mathrm{g} / \mu \mathrm{L}$ for sample $2,0.88 \mu \mathrm{g} / \mu \mathrm{L}$ for sample 3 , and $1.52 \mu \mathrm{g} / \mu \mathrm{L}$ for positive control. The SDS-PAGE gel was run at 100 Volt for $1 \mathrm{~h}$, and then it stained with Coomassie Brilliant Blue R-250.

\subsection{Western blotting}

The expressed recombinant F protein of NDV was visualized by Western blotting. As a positive control, Aequore courulescens GFP fluorescent protein (AcGFP) with a molecular weight of $28.0 \mathrm{kDa}$ on lane with a concentration of $1.52 \mu \mathrm{g} / \mu \mathrm{L}$ was used. The recombinant F protein was separated by a $12 \%$ resolving SDS-PAGE gel. They were then electrotransferred onto polyvinylidene difluoride (PVDF) membrane (Merck) for detecting the recombinant $\mathrm{F}$ protein. Western blotting preparation was performed by blocking the membrane by the blocking solution [1\% BSA (Thermo Fisher Scientific) dissolved in 0.5\% Tween-PBS (Sigma-Aldrich)]. The PVDF membrane was then incubated at room temperature for $1 \mathrm{~h}$. After washed three times in washing solution $(0.05 \%$ TweenPBS), the PVDF membrane was probed with a mouse monoclonal antibody, anti-6x histidine (his)-tag antibody (Thermo Fisher Scientific) as the primary antibody in a 1:2,000 dilution. The membrane was then incubated and shaken overnight at $4{ }^{\circ} \mathrm{C}$. After three time washing, the PVDF membrane was subsequently incubated with the secondary antibody, alkaline phosphatase (AP)conjugated goat antimouse IgG antibody (Thermo Fisher
Scientific) in a 1:15,000 dilution. The PVDF membrane was then incubated and shaken at room temperature for 1 h. After two time washing, the immunological reaction was visualized by adding NBT-BCIP (Thermo Fisher Scientific) substrate onto the PVDF membrane.

\section{Results and Discussion}

\subsection{Transformation plasmid pBT-7-N-His-Fusion NDV into $E$. coli BL 21 and visualization of recombinant NDV fusion protein expression}

The transformation of pBT7-N-His-Fusion-NDV recombinant plasmid was performed initially on E. coli BL21 (DE-3) competent cell. The transformation result indicated that there were eight colonies of $E$. coli grew on agar LB medium (Figure 2). To confirm the result of the recombinant plasmid transformation, three from the eight colonies were selected for DNA isolation of recombinant. The next process was restriction endonuclease analysis by digestion recombinant plasmid pBT7-N-His-Fusion-NDV using Eco RI restriction enzyme. Recombinant plasmid digestion resulted two DNA bands in size of 3,959 bp (plasmid) and 642 bp (insert gene), respectively, while the undigested recombinant plasmid was observed to be 4,601 bp in size (Figure 3). The undigested recombinant plasmid which was run by electrophoresis in agarose gel showed three bands of DNA because it had three forms of conformation: relaxed circular form, linearized form, and superhelix form (De Mattos et al. 2004).

In Figure 4, electrophoresis using SDS-PAGE of recombinant $\mathrm{F}$ protein on the agarose gel $12 \%$ with Coomassie Brilliant Blue staining showed that recombinant F protein of NDV could be expressed as a thick pro-

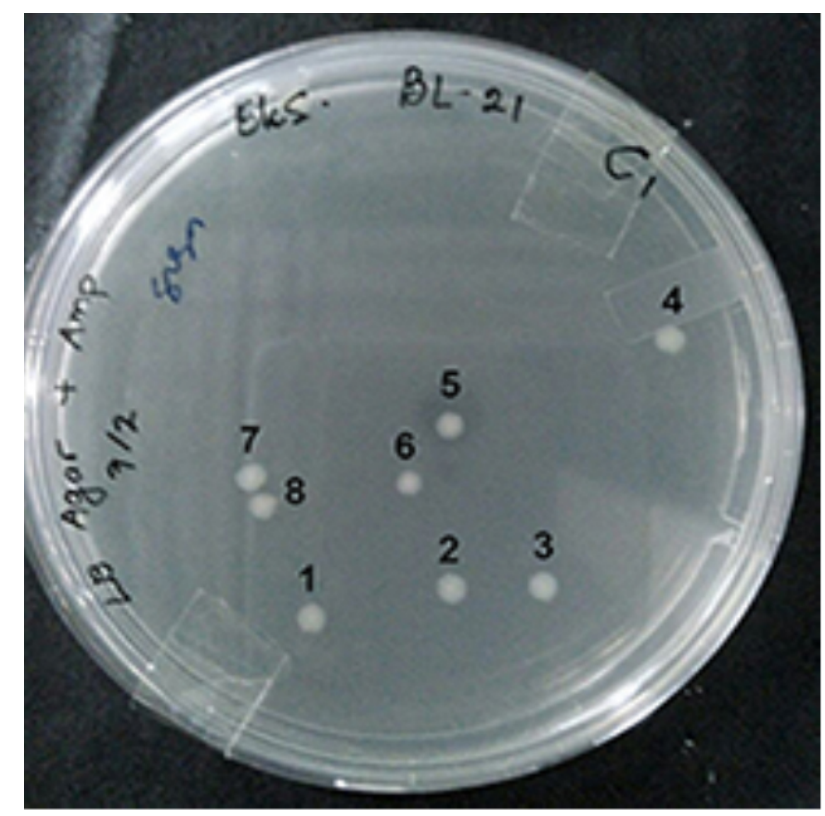

FIGURE 2 Eight growing colonies of E. coli BL21 carrying recombinant plasmid pBT7-N-His-Fusion-NDV in LB agar medium with ampicillin. 


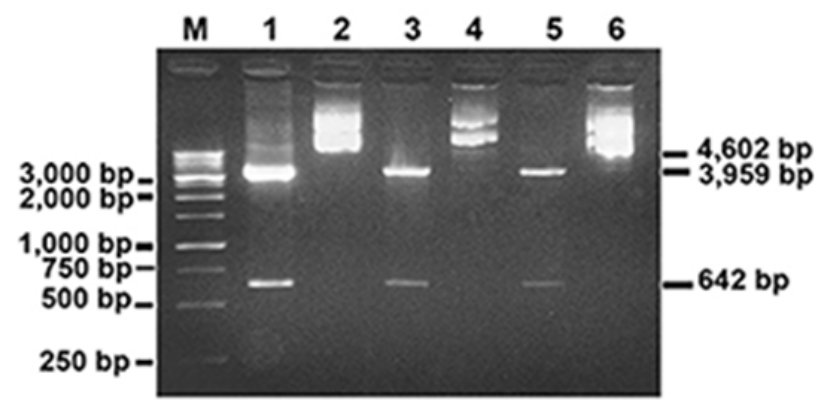

FIGURE 3 The digestion result of recombinant plasmid pBT-N-HisFusion-NDV by using Eco RI enzyme. No. 1 is recombinant plasmid of Colony-1 (C-1) was digested by Eco RI, No. 2 is an intact recombinant of C-1, No. 3 is recombinant plasmid of Colony-2 (C-2) was digested by Eco RI. No. 4 is an intact recombinant plasmid of C-2, No. 5 is recombinant plasmid of Colony-3 (C-3) was digested by Eco RI, No. 6 is an intact recombinant plasmid of C-3.

tein band with the molecular weight of $25.6 \mathrm{kDa}$ (lane 1, 2, 3). Meanwhile, AcGFP with the molecular weight of $28.0 \mathrm{kDa}$ on lane $(+)$ appeared as the positive control. The recombinant F protein of NDV which expressed using cellfree protein expression system found in the supernatant after incubated for $3 \mathrm{~h}$ at $30^{\circ} \mathrm{C}$. It indicated that the expressed recombinant $\mathrm{F}$ protein of NDV in this expression system is a soluble protein. This soluble protein can be reactivated and followed by a refolding process with dilution or dialysis method in refolding buffer to obtain active soluble protein (Middelberg 2002; Burgess 2009; Yang et al. 2011).

\subsection{Western blotting}

Western blotting using a mouse antihistidin-tag antibody as the primary antibody and goat antimouse antibody as the secondary antibody was conducted to assure the result of recombinant F protein of NDV expression. The result of Western blotting can be seen in Figure 5. It showed a

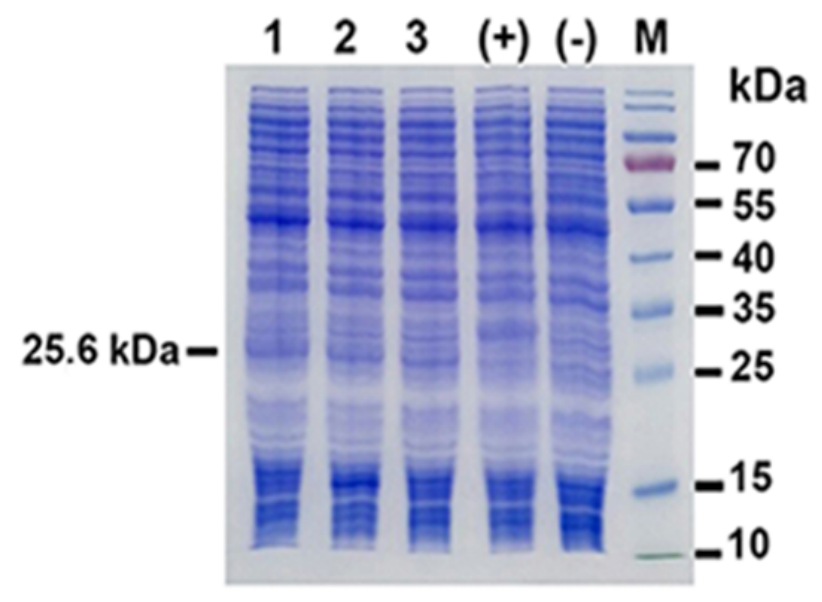

FIGURE 4 SDS-PAGE with Coomassie Brilliant Blue staining of the expressed recombinant $F$ protein of NDV into $E$. coli extract. No. 1 is a recombinant plasmid of Colony-1 (C-1), No. 2 is a recombinant plasmid of Colony-2 (C-2). No. 3 is a recombinant plasmid of Colony-3 (C-3), (+) is positive control, (-) is negative control

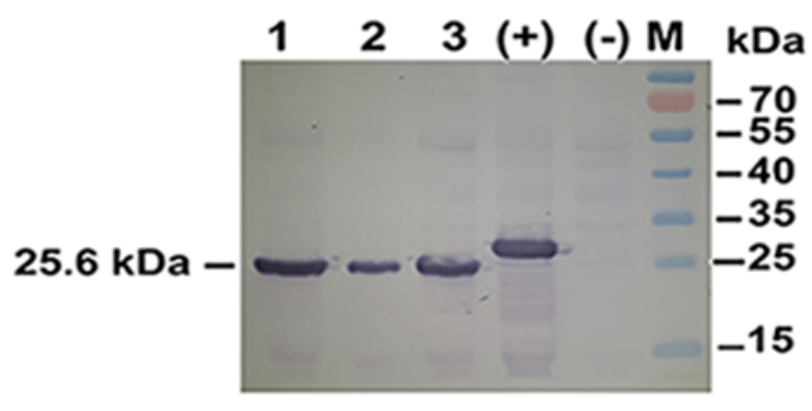

FIGURE 5 Western blotting of the recombinant F protein of NDV $\mathrm{M}=$ protein marker. No. 1,2 , and 3 are Colony-1 (C-1), Colony-2 (C-2), and Colony-3 (C-3), respectively. $(+)=$ positive control. $(-)=$ negative control.

specific protein band with a molecular weight of $25.6 \mathrm{kDa}$ at lane $1,2,3$. The positive control AcGFP protein with a molecular weight of $28.0 \mathrm{kDa}$ could be observed in lane $(+)$. Both recombinant F protein of NDV in lane 1, 2, 3 and AcGFP in lane $(+)$ were fusion protein with $6 x$ his-tag at the $\mathrm{N}$-terminus end.

\subsection{Discussion}

The recombinant expression plasmid that we designed pBT7-N-His-Fusion-NDV (4,601 bp) was derived from pBT7-N-His plasmid which having the origin of replication (ORI) from pUC plasmid. This plasmid carried the F protein encoding gene from NDV which was isolated from Indonesian local isolate. Recombinant $\mathrm{F}$ protein expressed from pBT7-N-His-Fusion-NDV will be prepared as a candidat vaccine for viral diseases, ND, in poultry based on local isolate virus. The expression of recombinant $\mathrm{F}$ protein from pBT7-N-His-Fusion-NDV plasmid vector was controlled by T7 promoter (Bioneer 2016). The expression system was controlled by T7 promoter, which could be induced through inducing lactose analog compound, namely isopropyl $\beta$-D-thiogalactoside (IPTG) (Rosano and Ceccarelli 2014). pBT7-N-His-Fusion-NDV has a multi cloning site (MCS) and stop codon (TGA) areas with nucleotide sequences that can be digested by certain endonuclease restriction enzymes. In this plasmid, there is a ribosome binding site (RBS) that facilitates the translation process. This vector plasmid also has pUC Ori which is an initial area for DNA replication. In addition, there is a $\beta$ lactamase encoding gene which functions in the resistance against ampicillin, which can be used in for selection of recombinant E. coli.

The expression of recombinant protein is a translation process from gene into protein through the processes of transcription and translation. Expression of protein could be performed using a prokaryotic cell system with $E$. coli or eukaryotic cells using yeast, filamentous fungi, and unicellular algae. The selection of the host system depended on the target protein which was going to be expressed. In this research, the expression of recombinant NDV F protein was performed by using $E$. coli extract in a cell-free protein expression system. This system was selected because a prokaryotic cell is one of the selected organisms to 
produce a recombinant protein (Wilson and Walker 2010). In pBT7-N-His-Fusion-NDV expression plasmid, recombinant $\mathrm{F}$ protein is expressed as a fusion protein with $6 \mathrm{x}$ his-tag (tag polyhistidine) at the N-terminus end. After the purification process, the expressed recombinant $F$ protein of NDV would be used as a candidate of recombinant vaccine against ND based on Indonesian local isolate of NDV strain. The existence of $6 x$ his-tag in the recombinant $\mathrm{F}$ protein of NDV did not affect the structure and function of the recombinant protein (Ramos et al. 2004). Polyhistidine tag can function as the epitope for protein detection in Western blot. Polyhistidine tag also functioned for binding with $\mathrm{Ni}^{2+}$ in the protein purification process (Sambrook and Green 2012). The benefit of using a polyhistidine tag was the recombinant F protein could be purified in the denatured condition because the interaction between histidine residue and Ni-NTA in the purification column could be stable with the existence of strong protein denaturant as guanidine $\mathrm{HCl}$ and urea. The purified recombinant protein can be renatured by slowly removing the denaturant (Terpe 2003).

In order to obtain high gene expression, the expression can be performed on E. coli since it grows fast, the enriched growth medium for $E$. coli is affordable, and the process of DNA transformation on $E$. coli is fast and easy (Qiagen 2001). E. coli BL21 (DE3) is a prokaryotic cell used for gene expression regulated by T7 promoter. This strain carries lysogen $\lambda D E 3$ containing lacI gene, RNA polymerase T7 RNA controlled by lacUV5 promoter, and a small part of lacZ gene (Wulanjati 2016). The expression of the recombinant F protein of NDV could be influenced by several factors, including vector plasmid, target protein, and strain bacteria used in the protein expression. Various internal factors of the plasmid which could influence the expression are promoter, initiation region, terminator region, enhancer, ribosome binding site, origin of replication, resistance marker against antibiotic, and the number of plasmid copy. Meanwhile, other factors of target protein which could influence the expression are nucleotide sequences, amino acid sequences, secondary structures of the protein, and the suitable codon usage (Makrides 1996; Rosano and Ceccarelli 2014). Besides, the productivity of the recombinant protein expression could be enhanced by optimization of external factors such as the temperature of bacterial growth and the level of expression-inducing compound (Chen et al. 2007; Volontè et al. 2008; Larentis et al. 2011, 2014).

Expression of NDV F protein encoding gene have been conducted by some researchers. For example, Chen et al. (2001) conducted cloning and full-length expression of cDNA from NDV $F$ gene isolate $V_{4}$ (Queensland/66strain) on mammal's cell in Chinese Hamster Ovary (CHO-K1) and its mutant line cell Lec- 3.2.8.1. Park et al. (2014) developed a virus-like particles (VLP) vaccine by expressing NDV F protein with Sf9 cell to obtain recombinant protein of baculovirus (rBV). In this work, we used local isolates of NDV from Kulon Progo, Yogyakarta, Indonesia, whose pathotype characterization has been identified by Haryanto et al. (2015). The result of this work showed that the recombinant $F$ protein of NDV was successfully expressed by a cell-free protein expression system and visualized by using SDS-PAGE electrophoresis with Coomassie Brilliant Blue staining and Western blot as a specific protein with a molecular weight of $25.6 \mathrm{kDa}$. This result was in line with the recombinant protein study performed by other researchers, who have successfully expressed the recombinant F protein of NDV from E. coli clone of C-1a (Putri and Haryanto 2019).

The cell-free protein expression system is one of in vitro protein expression methods to study biological reactions in a cell using a living cell system that reduces complex interactions on living cells, so the transcription, translation, and cell metabolism processes occur in an open environment. This system aims to understand, utilize, and extend natural biological system capability without using living cells (Hodgman and Jewett 2012). The expressed recombinant $\mathrm{F}$ protein of NDV which had been purified, had the potential as a candidate of recombinant $F$ vaccine for NDV based on the local isolate.

\section{Conclusions}

The fusion protein encoding gene of NDV subcloned into the pBT7-N-His expression vector has been successfully in vitro expressed by a cell-free protein expression system. Visualization by using Coomassie Brilliant Blue staining on SDS-PAGE gel and Western blot confirmed that the recombinant F protein of NDV expressed as a specific recombinant protein with a molecular weight of $25.6 \mathrm{kDa}$.

\section{Acknowledgments}

We would like to thank the head office of the Biochemistry Department, Faculty of Veterinary Medicine, Universitas Gadjah Mada (UGM), Yogyakarta, Indonesia and the head office of Inter-University Center for Biotechnology UGM, Yogyakarta, Indonesia for the opportunity and for allowing us to use the laboratory facilities to finish this work.

\section{Authors' contributions}

$\mathrm{AH}$ was responsible for the overall stage of research (recombinant plasmid preparation, laboratory works, drafting, and completing the final manuscript). HW did samples preparation, performed the laboratory works, and analyzed data. NW analyzed final data, drafted, and revised the manuscript. All authors read and approved the final version of the manuscript.

\section{Competing interests}

The authors declare no competing interest. 


\section{References}

Alexander DJ. 2003. Newcastle Disease, Other Avian Paramyxoviruses, and Pneumovirus Infections. In: Y Salf, H Brnes, J Glisson, A Fadly, L Mc Douglad, D Swayne, editors, Diseases of Poultry. Ames: Iowa State Press, 11th edition. p. 63-100.

Alexander DJ, Aldous EW, Fuller CM. 2012. The long view: a selective review of 40 years of Newcastle disease research. Avian Pathol. 41(4):329-335. doi:10.1080/03079457.2012.697991.

Arora P, Lakhchaura BD, Garg SK. 2010. Evaluation of immunogenic potential of $75 \mathrm{kDa}$ and $56 \mathrm{kDa}$ proteins of newcastle disease virus (NDV). Indian J Exp Biol 48(9):889-895.

Bioneer. 2016. Vector Information: pBT7-N-His.

Burgess RR. 2009. Chapter 17 Refolding Solubilized Inclusion Body Proteins. In: RR Burgess, MP Deutscher, editors, Methods in Enzymology: Vol 463 Guide to Protein Purification, volume 463. Academic Press Inc., 2nd edition. p. 259-282. doi:10.1016/S0076-6879(09)63017-2.

Chang A, Dutch RE. 2012. Paramyxovirus fusion and entry: Multiple Paths to a common end. Viruses 4:613636. doi:10.3390/v4040613.

Chen L, Colman PM, Cosgrove LJ, Lawrence MC, Lawrence LJ, Tulloch PA, Gorman JJ. 2001. Cloning, expression, and crystallization of the fusion protein of Newcastle disease virus. Virology 290(2):290-299. doi:10.1006/viro.2001.1172.

Chen Y, Xing XH, Ye F, Kuang Y, Luo M. 2007. Production of MBP-HepA fusion protein in recombinant Escherichia coli by optimization of culture medium. Biochem Eng J. 34(2):114-121. doi:10.1016/j.bej.2006.11.020.

De Leeuw O, Peeters B. 1999. Complete nucleotide sequence of Newcastle disease virus: Evidence for the existence of a new genus within the subfamily Paramyxovirinae. J Gen Virol. 80(1):131-136. doi:10.1099/0022-1317-80-1-131.

De Mattos JC, Dantas FJ, Caldeira-De-Araújo A, Moraes MO. 2004. Agarose gel electrophoresis system in the classroom: Detection of DNA strand breaks through the alteration of plasmid topology. Biochem Mol Biol Educ. 32(4):254-257. doi:10.1002/bmb.2004.494032040382.

Dharmayanti NI, Risza H, Dyah AH, Risa I. 2014. Phylogenetic analysis of genotype VII of new castle disease virus in Indonesia. African J Microbiol Res. 8(13):1368-1374. doi:10.5897/ajmr2014.6601.

Dortmans JC, Koch G, Rottier PJ, Peeters BP. 2011. Virulence of newcastle disease virus: What is known so far? Vet Res. 42(1). doi:10.1186/1297-9716-42-122.

Ganar K, Das M, Sinha S, Kumar S. 2014. Newcastle disease virus: Current status and our understanding. Virus Res. 184:71-81. doi:10.1016/j.virusres.2014.02.016.

Grand LRL, White M, Siegel EB, Barnard RT. 2012.
Recombinant Vaccines: Development, Production, and Application. In: O Kayser, H Warzecha, editors, Pharmaceutical Biotechnology: Drug Discovery and Clinical Applications, chapter 17. Hoboken (NJ): John Wiley \& Sons, Ltd\},, 2nd edition. p. 423-449. doi:10.1002/9783527632909.ch17.

Haryanto A, Ermawati R, Wati V, Irianingsih SH, Wijayanti N. 2016. Analysis of viral protein-2 encoding gene of avian encephalomyelitis virus from field specimens in Central Java region, Indonesia. Vet World. 9(1):25-31. doi:10.14202/vetworld.2016.25-31.

Haryanto A, Purwaningrum M, Verawati S, Irianingsih SH, Wijayanti N. 2015. Pathotyping of Local Isolates Newcastle Disease Virus from Field Specimens by RT-PCR and Restriction Endonuclease Analysis. Procedia Chem. 14:85-90. doi:10.1016/j.proche.2015.03.013.

Hodgman CE, Jewett MC. 2012. Cell-free synthetic biology: Thinking outside the cell. Metab Eng. 14(3):261-269. doi:10.1016/j.ymben.2011.09.002.

Jeon WJ, Lee EK, Lee YJ, Jeong OM, Kim YJ, Kwon JH, Choi KS. 2008. Protective efficacy of commercial inactivated Newcastle disease virus vaccines in chickens against a recent Korean epizootic strain. J Vet Sci. 9(3):295-300. doi:10.4142/jvs.2008.9.3.295.

Kim SH, Wanasen N, Paldurai A, Xiao S, Collins PL, Samal SK. 2013. Newcastle Disease Virus Fusion Protein Is the Major Contributor to Protective Immunity of Genotype-Matched Vaccine. PLoS ONE 8(8). doi:10.1371/journal.pone.0074022.

King AM, Adams MJ, Carstens EB, Lefkowitz EJ. 2012. Virus Taxonomy: Classification and Nomenclature of Viruses. Elsevier. doi:10.1016/B978-0-12-3846846.00057-4.

Lamb R, Parks G. 2007. Fields’ Virology, Volume 1. In: BN Fields, DM Knipe, PM Howley, editors, Paramyxoviridae: the viruses and their replication. Philadelphia: Lippincott, Williams and Wilkins, 5th edition. p. 1449-1496.

Larentis AL, Nicolau JFMQ, Esteves GDS, Vareschini DT, De Almeida FVR, Dos Reis MG, Galler R, Medeiros MA. 2014. Evaluation of pre-induction temperature, cell growth at induction and IPTG concentration on the expression of a leptospiral protein in E. coli using shaking flasks and microbioreactor. BMC Res Notes. 7(1). doi:10.1186/1756-0500-7-671.

Larentis AL, Sampaio HDCC, Martins OB, Rodrigues MI, Alves TLM. 2011. Influence of induction conditions on the expression of carbazole dioxygenase components (CarAa, CarAc, and CarAd) from Pseudomonas stutzeri in recombinant Escherichia coli using experimental design. J Ind Microbiol Biotechnol. 38(8):1045-1054. doi:10.1007/s10295-010-0879-2.

Makrides SC. 1996. Strategies for achieving high-level expression of genes in Escherichia coli. Microbiol Rev. 60(3):512-538. doi:10.1128/mmbr.60.3.512538.1996.

Middelberg AP. 2002. Preparative protein re- 
folding. Trends Biotechnol. 20(10):437-443. doi:10.1016/S0167-7799(02)02047-4.

Miller PJ, King DJ, Afonso CL, Suarez DL. 2007. Antigenic differences among Newcastle disease virus strains of different genotypes used in vaccine formulation affect viral shedding after a virulent challenge. Vaccine 25(41):7238-7246. doi:10.1016/j.vaccine.2007.07.017.

Morrison TG. 2003. Structure and function of a paramyxovirus fusion protein. Biochim Biophys Acta, Biomembr. 1614(1):73-84. doi:10.1016/S00052736(03)00164-0.

Nascimento IP, Leite LC. 2012. Recombinant vaccines and the development of new vaccine strategies. Brazilian J Med Biol Res. 45(12):1102-1111. doi:10.1590/S0100-879X2012007500142.

Njoto EN, Scotch M, Bui CM, Adam DC, Chughtai AA, MacIntyre CR. 2018. Phylogeography of H5N1 avian influenza virus in Indonesia. Transboundary Emerging Dis. 65(5):1339-1347. doi:10.1111/tbed.12883.

[OIE] Office International of Epizootics. 2012. Newcastle disease infection with newcastle disease virus.

[OIE] Office Internationalof Epizootics. 2015. Old classification of diseases notifiable to the OIE: List A. URL http://www.oie.int/en/animal-health-in-the-world/th e-world-animal-health-information-system/old-class ification-of-diseases-notifiable-to-the-oie-list-a/.

Parede LH, Sapats S, Gould G, Rudd M, Lowther S, Ignjatovic J. 2003. Characterization of infectious bursal disease virus isolates from Indonesia indicates the existence of very virulent strains with unique genetic changes. Avian Pathol. 32(5):511518. doi:10.1080/0307945031000154116.

Park JK, Lee DH, Yuk SS, Tseren-Ochir EO, Kwon JH, Noh JY, Kim BY, Choi SW, Kang SM, Lee JB, et al. 2014. Virus-like particle vaccine confers protection against a lethal newcastle disease virus challenge in chickens and allows a strategy of differentiating infected from vaccinated animals. Clin Vaccine Immunol. 21(3):360-365. doi:10.1128/CVI.00636-13.

Putri CN, Haryanto A. 2019. Fusion recombinant protein expression of newcastle disease virus from Escherichia coli-Cloned C1a using accurapidTM protein expression kit. IOP Conference Series: Earth and Environmental Science 355(1). doi:10.1088/17551315/355/1/012026.

Qiagen. 2001. The QIA expressionist: a handbook for high-level expression and purification of 6xHistagged protein.

Ramos CR, Abreu PA, Nascimento AL, Ho PL. 2004. A high-copy T7 Escherichia coli expression vector for the production of recombinant proteins with a minimal N-terminal his-tagged fusion peptide. Brazillian J Med Biol Res. 37(8):1103-1109. doi:10.1590/S0100879X2004000800001.

Rosano GL, Ceccarelli EA. 2014. Recombinant protein expression in Escherichia coli: Advances and challenges. Frontiers in Microbiology 5(APR). doi:10.3389/fmicb.2014.00172.

Sambrook J, Green M. 2012. Molecular Cloning: A Laboratory Manual. New York: Cold Spring Harbor Laboratory Press, 4th edition.

Terpe K. 2003. Overview of tag protein fusions: From molecular and biochemical fundamentals to commercial systems. Appl Microbiol Biotechnol. 60(5):523533. doi:10.1007/s00253-002-1158-6.

Volontè F, Marinelli F, Gastaldo L, Sacchi S, Pilone MS, Pollegioni L, Molla G. 2008. Optimization of glutaryl-7-aminocephalosporanic acid acylase expression in E. coli. Protein Expression Purif. 61(2):131-137. doi:10.1016/j.pep.2008.05.010.

Wilson K, Walker J. 2010. Principles and Techniques of Biochemistry and Molecular Biology. Cambridge: Cambrige University Press, 7th edition. doi:10.1017/cbo9780511841477.

Wulanjati M. 2016. Ekspresi protein rekombinan Fusion (F) virus Newcastle disease isolat lokal pada Escherichia coli BL21 (DE3) [Expression of recombinant Fusion (F) protein of Newcastle Disease Virus from local isolates on Escherichia coli BL-21 (DE.3)]. Master thesis, Universitas Gadjah Mada.

Wulanjati MP, Wijayanti N, Haryanto A. 2018. Phylogenetic analysis of Newcastle disease virus from Indonesian isolates based on DNA-sequence of fusion protein-encoding gene. Biotechnology 17(2):69-74. doi:10.3923/biotech.2018.69.74.

Xiao S, Paldurai A, Nayak B, Samuel A, Bharoto EE, Prajitno TY, Collins PL, Samal SK. 2012. Complete Genome Sequences of Newcastle Disease Virus Strains Circulating in Chicken Populations of Indonesia. J Virol. 86(10):5969-5970. doi:10.1128/jvi.00546-12.

Yang Z, Zhang L, Zhang Y, Zhang T, Feng Y, Lu $\mathrm{X}$, Lan $\mathrm{W}$, Wang $\mathrm{J}$, Wu $\mathrm{H}$, Cao C, Wang $\mathrm{X}$. 2011. Highly efficient production of soluble proteins from insoluble inclusion bodies by a Two-StepDenaturing and refolding method. PLoS ONE 6(7). doi:10.1371/journal.pone.0022981. 